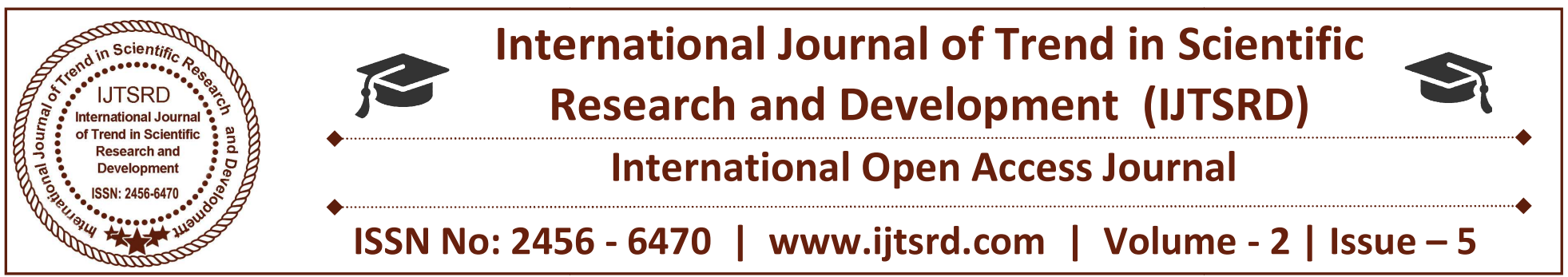

\title{
A Study on Issues and Challenges of Women Empowerment in Indian Railways
}

\author{
Ranjith Kumar \\ Research Scholar, Department of P. G. Studies and Research in Economics \\ Kuvempu University, Shankaraghatta, Shivamogga, Karnataka, India
}

\begin{abstract}
Indian Railway- a name with which daily lives of crores of middle-class and low-class Indians are deeply involved, an industry that has eased up the lives of many at affordable price, and a very important tangible part of Indian Economy that flows throughout the country touching almost every corneralways. The women workers are the part of our Indian railways as well as Indian economy. This paper attempts to analyze the issues and challenges of Women Empowerment in Indian railways. Today the empowerment of women has become one of the most important concerns of 21 st century especially Indian railways. Women empowerment it can also point to approaches regarding other trivialized genders in particular political or social contexts. The study is based on purely from secondary sources. The study reveals that women of India railways are relatively disempowered and they enjoy somewhat lower status than that of men in spite of many efforts undertaken by Government. The study concludes by an observation that access to facilities, percentage of female worker and analyses of railways committee report for the empowerment of women.
\end{abstract}

Keywords: Women Empowerment, Middle-Class, Social Contexts, Disempowered

\section{INTRODUCTION}

Indian Railways is one of the world's largest railway networks, providing both passenger and freight services. It is also the largest public sector employer in the country with $13,33,966$ employees as on 31stMarch, 2014 out of which 89,337 are

women employees. Being the lifeline of the country and considering the volume of passengers it handles every day, the employees in Railways including women require working round the clock to ensure the smooth running of the railways.

The Railways, being a surface transport sector, involves many jobs which are arduous in nature and perceived to be tough for a woman to handle. Hence, in order to render optimum efficient service, the women employees in Railways require customized working conditions that would cater to their unique job needs. Further, in view of the fact that a large section of its commuters are women, the responsibility of the Railways is huge in terms of providing necessary amenities and security to its women passengers in station premises and onboard trains. Railways are a male-dominated industry. Women in the railway industry tend to work in administration, sales, catering and cleaning. They are also more likely to be found in outsourced positions.

\section{Review of Literature}

M. Bhavani Sankara Rao (2011) has highlighted that health of women members of SHG have certainly taken a turn to better. It clearly shows that heath of women members discuss among themselves about health related problems of other members and their children and make them aware of various Government provisions specially meant for them.

Kamini B. Dashora in their paper "Problems faced by Working Women in India" published in International Journal of Advanced Research in Management and Social Sciences (2013) states that a gender bias creates lot of hurdles while remunerating the women at the workplace. There is an old belief 
that women are less capable and less efficient than men and hence deserve unequal salaries and wages for the same job.

Morse (2001) discusses the occupation stress among the working women, influence of feminism, educated women, women related problem like childcare, low pay, sexual harassment, problems pregnant women, psychological problems, family life, work satisfaction, happiness of working women. Job related psychological stressors for the working women are fear of disapproval, feeling of dependency on male co-workers, need to submerge her own desires, fear of being aggressive, or self - assertive and hence, being labelled unfeminine, fear of failure, etc.

\section{Objectives of the Study}

1. To know the need of Women Empowerment in Railways.

2. To study the status of Women Employees in Indian Railways.

3. To analyze the annual railways committee report on women empowerment.

\section{Methodology}

Data source: The study is based on secondary data collected from Ministry of Railway's, Railway Year Books, Annual Reports and data collected from Planning Commission, Ministry of Statistics and Programme Implementation and Railway Committee Report on Women Empowerment.

\section{Analysis and Interpretation}

Now-a-days in Indian railways women employee total 89,337 for the out of $13,33,966$ compare to men employee is less. $6.7 \%$ of the Indian Railways' employees are female. These missing women pose a major challenge to the company's message of progress. The Indian Railways is bounding forward with modern advancements. It plans to use Twitter to issue customer complaints, an app for booking paperless tickets, handheld terminals for ticket examiners, and a Google partnership to provide free Wi-Fi at the 100 busiest stations, an online Track Management System, an e-procurement system, and more. Every day, the Indian Railways transports an average of $\mathbf{2 3}$ million originating passengers and over 2.9 million tons of freight cargo. With consumer demand for public transportation already surpassing supply, Minister of Railways Suresh Prabhakar Prabhu is smart to work toward efficiency and transparency in the Indian Railways.
Unfortunately, the need for advancement is not confined to technology. With more than 1.3 million employees, the Indian Railways is the largest employer in India. However, less than 6.7 per cent of its employees are women (as on March 31, 2014). This means there is only 1 female employee for every 14 male employees.

About 270,836 women are 'Missing' from the Indian Railways' Employee Roster. If the company adhered to India's average female workforce participation rate (27\%), we'd expect to see 360,171 female employees at the Indian Railways. However, there are only 89,335 female employees. These missing women are a major flaw in the Indian Railways' message of progress.

\section{Strength of Women Employees in Railways}

There are four basic nature of jobs in the Railways where women staff are engaged:

1. Passenger interface or the public reservation offices,

2. Train Operation

3. Railway hospitals,

4. Production units and workshops.

With regard to the cadre wise number and percentage of women employees working in the Railways, the Ministry, in a written reply, submitted the following details:

\section{Cadre-wise Number and Percentage of Women} Employees

\begin{tabular}{|c|c|c|c|c|}
\hline $\begin{array}{c}\text { Particular } \\
\text { s }\end{array}$ & $\begin{array}{c}\text { Officer } \\
\text { s } \\
\text { Groups } \\
- \text { A and } \\
\text { B }\end{array}$ & $\begin{array}{c}\text { Group- } \\
\text { C Staff }\end{array}$ & $\begin{array}{c}\text { Group } \\
- \text { D } \\
\text { Staff }\end{array}$ & Total \\
\hline $\begin{array}{c}\text { (01) } \\
\begin{array}{c}\text { Total No. } \\
\text { of } \\
\text { Employees }\end{array}\end{array}$ & 17062 & $\begin{array}{c}118791 \\
2\end{array}$ & $\begin{array}{c}12899 \\
2\end{array}$ & $\begin{array}{c}133396 \\
6\end{array}$ \\
\hline $\begin{array}{c}\text { Women } \\
\text { Employees }\end{array}$ & 1503 & 78889 & 8945 & 89337 \\
\hline $\begin{array}{c}\text { \% of } \\
\text { Women } \\
\text { Employees }\end{array}$ & 8.81 & 6.64 & 6.93 & 6.70 \\
\hline
\end{tabular}

Note:

Group-C Women Staff other than Workshop and Artisan Staff. 
Group-D Women Staff including Workshop and Artisan Staff.

Workshop and Artisan Staff $=1349$

Other than Workshop and Artisan Staff $=7596$

Source: Report on Railway Committee on Women Empowerment, April 2015.

On observing that the women employees constitute a mere $6.7 \%$ of the total employees in the Railways and their strength in Group 'A' and Group 'B' posts are negligible.

Representing railway workers around the world. Railway workers include train drivers, engineers, guards, control officers, signal staff, yard officials, shunters, rolling stock and track maintenance workers, cleaners, caterers, ticket staff and customer service professionals.

We fight for the rights of railway workers through:

$>$ Campaigning

$>$ Education

$>$ Research

$>$ Solidarity

We share information and coordinate action to combat the negative effects of restructuring, privatization and outsourcing

The challenges facing women railway workers

$>$ Women's roles tend to be the lowest paid in the railway industry

$>$ They struggle to reach management positions

$>$ Outsourcing results in a lack of job security and participation in unions

$>$ Barriers exist prohibiting women from working in certain functions - these can be legislative or as a result of company or management policy

$>$ Workplace health and safety issues e.g. violence and sexual harassment, maternity and pregnancy provisions

\section{Role of International Transport Federation (ITF) in Women Railway Workers}

In December 2008 in Brazil, ITF held its first meeting focusing on the issues faced by women railway workers.

The meeting addressed ongoing challenges, including:

$>$ Under representation of women in operations and technical functions, and managerial positions
$>$ The impact of restructuring and outsourcing on women in railways

$>$ Issues relating to pregnancy and maternity, violence and sexual harassment and discrimination

Women in trade unions: their representation and leadership at different levels.

It is our responsibility to raise awareness of the issues facing women within the railway industry. We also need to encourage women railway workers to join and participate in unions.

\section{Annual Railways Committee Report on Women Empowerment, April 2015}

The committee submitted reports on women empowerment 2015 and that report analyses the women working atmosphere in Indian railways and committee refer to over all development and more facilities the women worker in Indian railways. Like this,

$>$ Transfer and posting of women employees

Child care (Creches) and rest rooms

Working hours and conveyance facility

- Sexual harassment complaints / grievance redressal mechanism

Hostels/quarters for single women employees

\section{Findings}

Based on the present work, the following findings are drawn:

In Indian Railways women employees are less than the men employees.

Women employees' strength in group-A and B post are negligible.

Gender discrimination for employees.

Missing women are major flow in the Indian Railway in terms of roaster.

Nature of job in railways for women employees is not satisfactory.

\section{Suggestions}

Following are the suggestions for the present study:

$>$ Railways should conducting separate special requirement for women in Indian railways.

$>$ Provide skill oriented training programme for women employees in railways.

Combat violence against women employees.

To improve working environment for the women employees.

\section{Conclusion}


The attainment in the field of income / employment and in educational front, the scenario of women empowerment seems to be comparatively poor. The need of the hour is to identify those loopholes or limitations which are observing the realization of empowerment of women and this initiative must be started from the women folk itself as well as more importantly policy initiative taken by the state and society. Let us take the oath that we want an egalitarian society where everybody whether men or women get the equal opportunity to express and uplift one's well being and well being of the society as whole. The Empowerment of Women has become one of the most important concerns of 21 st century not only at national level but also at the international level. Government should implement programmes for women employees for the sake of empowerment and railways should develop centralized IT enabled employees information system at the earliest for easy access to information and Government initiatives alone would not be sufficient to achieve this goal. Society must take initiative to create a climate in which there is no gender discrimination and women have full opportunities of self decision making and participating in social, political and economic life of the country with a sense of equality. Then only the Vedic verse (Wherever Women is respected, God resides there) would come true.

\section{References}

1. Annual Committee Report on Women Empowerment in Indian Railways 2015.

2. Annual Report: Ministry of Human Resource Development, India, 2008.

3. Dunlop, J. E. and Velkoff, V. A. 1999. 'Women and the Economy in India', Working Paper, International Programs Center.

4. Ghosh, B. and Mukhopadhyay, S. K. 1984. Displacement of the Female in the Indian Labour Force, Economic and Political Weekly, Vol. 19, No. 47.

5. Indian Railway Portal.

6. Indian Railways Annual Report and Accounts, 2011-12.

7. Pankaj Kumar Barol and Rahul Sarania. Employment and Educational Status: Challenges of Women Empowerment in India, A PeerReviewed Indexed International Journal of Humanities \& Social Science.

8. Rajeshwari M. Shettar, "A Study on Issues and Challenges of Women Empowerment in India”.

9. http://www.indianrailway.co.in. 10. http://www.SWR.com. 